\title{
Evaluation of Six Sunflower Cultivar for Forage Productivity Under Salinity Condition
}

\author{
${ }^{1}$ Abu Obaid, A.M., ${ }^{2}$ Melnyk, A.V., ${ }^{2}$ Onichko, V.I., ${ }^{1}$ Ismael, F.M., ${ }^{1}$ Al-Abdullah, M.J., ${ }^{1}$ Al-Rifaee, M.K. and ${ }^{3}$ Tawaha, A.M. \\ ${ }^{1}$ Field Crops, Al-Khalediyah Agriculture Salinity Research Station, National Agricultural Research (NARC) P.O.Box 639 Amman Baqa`19381, Jordan. \\ ${ }^{2}$ Sumy National Agrarian University (SNAU), Sumy, Ukraine. \\ ${ }^{3}$ Department of Biological sciences, Al-Hussein bin Talal University, Maan, Jordan.
}

Correspondence Author: Abu Obaid, A.M.,, Field Crops, Al-Khalediyah Agriculture Salinity Research Station, National Agricultural Research (NARC) P.0.Box 639 Amman Baqa`19381, Jordan.

E-mail: Adib_abuobaid@yahoo.com

Received date: 19 April 2018, Accepted date: 15 July 2018, Online, Online date: 31 July 2018

Copyright: (c) 2018 Abu Obaid, A.M., et al. This is an open-access article distributed under the terms of the Creative Commons Attribution License, which permits unrestricted use, distribution, and reproduction in any medium, provided the original author and source are credited.

\begin{abstract}
Sunflower cultivars were introduced and evaluated under saline conditions in Jordan. Objective of this study were to determine the tolerance of sunflower cultivars for soil and water salinity and to select superior cultivars for local production using the available resources. Seeds from six cultivars were introduced from Russia and it was cultivated in saline soil (15.7 dS m-1) using saline water (5.6 dS m-1) for irrigation during the spring season of 2011. In our experiments the following traits were recorded: yield and yield components and some morphological traits. Our results indicated that the sun flower cultivars varied significantly in their productivities. For example "Carslien" cultivar gave the highest dry weight (630.8 g plant-1), and seed yield (92.5 g head-1) and also gave the largest head and seed size. Also Carslien" cultivar gave the highest dry biomass and seed yield 18.02 and $2.64 \mathrm{t}$ ha-1, respectively under saline soil and saline water conditions.
\end{abstract}

Key words: forage,Helianthus annuus, introduced cultivars, salinity, yield.

\section{INTRODUCTION}

Sunflowers are annual or perennial plants that are cultivated in temperate regions and has many uses such as raw material for silage, oil production and to its potential as a new source of energy from the biological fuel production. The spreading out the sunflower promising crop as the second summer crop in Jordan depends on a continuous evaluation of new cultivars obtained by the documentation of greater materials able to express high yield and acceptable quality in the different regions especially under saline conditions. The growth and t productively of crop is influenced by several biotic and abiotic stresses $[1,2,3,4,5,6,7,8,9,10,11,12,13,14,15,16,17,18]$. Tanji [19] reported that salinity is one of the main factors limiting crop productivityby inhibiting plant growth as a result of many stress factor such as drought and mineral toxicity[20] which reflected adversely by the inhibition of plant leaf expansion and biomass production [21].Jordan is considered as one of the ten most water-poor countries in the world and we use saline water for increasing agricultural production. The present study was designed to evaluate six promising sunflower cultivar grown under salinity conditions.

\section{MATERIAL AND METHODS}

The study was carried out in Al-Kahlediyah (Marfaq), Jordan in an area measuring approximately $350 \mathrm{~m}^{2}$. The soil at the site is calcareous, $\mathrm{pH} 7.5$, clay loam textured and salinity of $15.7 \mathrm{dS} \mathrm{m}^{-1}$. The climate is Mediterranean of mild rainy winters and dry hot summers. The longer term rain average is $120 \mathrm{ml}$ per year.

Six sunflower cultivars were introduced from Russia; Carslien, Vezate, Bostiyalnske, Darae, Tshass and Kharfksky. The cultivars were evaluated for the yield and yield components. Seeds were grown in mid-April and harvested at maturity in July. Sowing was by hand in a wide spaced $(70 \times 50 \mathrm{~cm})$ plots of $16.8 \mathrm{~m}^{2}$ area in three replications and arranged in a one factor randomized complete block design. The trial lands were irrigated by adding $400 \mathrm{~mm}$ distributed as three days interval after sowing. Irrigation water was from underground well with salinity of $5.6 \mathrm{dS} \mathrm{m}^{-1}$. Random plant samples within each plot were used to record the morphological data. At harvest random single plants from each plot were harvested to determine the yield and yield components on single plant bases. Estimations were calculated for the dry biological yield, seed yield and the harvest index (HI). Data for each trait were analyzed for a randomized complete block design (RCBD). Comparisons between means were made using least significant differences (LSD) at 0.05 probability level

\section{RESULTS AND DISCUSSION}

Morphological characters:

Crop productivity under saline condition is considered very important issue in the world. For this reason many strategies have been proposed, one of which is the use of salt tolerant species [22].

Our results indicated that Sunflower cultivars differed significantly in their plant height (Table 1), where Bostiyalnske and Carslien gave the highest plant height compared with other cultivars.

Regarding number of leaves per plant our results indicated that no significant differences were recored among cultivars. On the other hand, Carslien cultivar gave significantly the highest head diameter compared with other cultivars. The variation was attributed to the differences in genetic potential among sunflower cultivars. 
Citation: Abu Obaid, A.M., et al, 2018. Evaluation of Six Sunflower Cultivar for Forage Productivity Under Salinity Condition. Advances in Environmental Biology., 12(7): 13-15.

Table 1: Morphological characterization of sunflower cultivars grown under saline condition.

\begin{tabular}{|l|l|l|l|l|l|}
\hline \multirow{2}{*}{ Cultivar } & Plant Height & Leaf plant & Head Diameter & Head Dry Weight & Seed head $^{-1}$ \\
\cline { 2 - 6 } & Cm & no. & cm & gm & no \\
\hline Carslien & 67.67 & 21.50 & 19.67 & 276.7 & 1028.0 \\
\hline Vezate & 55.00 & 21.17 & 18.17 & 268.5 & 889.3 \\
\hline Bostiyalnske & 74.83 & 20.83 & 17.33 & 193.8 & 884.0 \\
\hline Darae & 61.83 & 21.83 & 17.67 & 244.7 & 1013.0 \\
\hline Tshass & 21.00 & 17.33 & 228.3 & 841.3 \\
\hline Kharfksky & 21.67 & 18.17 & 244.2 & 1182.0 \\
\hline & 58.67 & & & & \\
\hline LSD $(0.05 \%)^{* *}$ & 11.42 & NS & 1.571 & 73.58 & 213.9 \\
\hline CV \%* & 10.43 & 9.68 & 34.26 & 25.2 \\
\hline
\end{tabular}

*Least significant difference

***eefficient of variability; NS =not significant

Yield and yield components:

Our data indicated that Our results indicated that the sun flower cultivars varied significantly in their productivities. For example "Carslien" cultivar gave the highest dry weight $\left(630.8 \mathrm{~g} \mathrm{plant}^{-1}\right)$, and seed yield $\left(92.5 \mathrm{~g} \mathrm{head}^{-1}\right)$ and also gave the largest head and seed size. Also Carslien" cultivar gave the highest dry biomass and seed yield 18.02 and $2.64 \mathrm{t} \mathrm{ha}^{-1}$, respectively under saline soil and saline water conditions. These differences among genotypes were probably related mainly to the differences in their genetic potential.

Table 2: Yield and yield components of sunflower cultivars grown under saline condition.

\begin{tabular}{|c|c|c|c|c|c|c|}
\hline Cultivar & $\begin{array}{l}\text { Plant Dry } \\
\text { Weight }\end{array}$ & $\begin{array}{l}\text { Seed Dry Weight head' } \\
{ }^{1} \text { plant }^{-1}\end{array}$ & 1000 Seed Weight & $\begin{array}{l}\text { Estimated } \\
\text { Biological Dry } \\
\text { Weight }\end{array}$ & $\begin{array}{l}\text { Estimated Seed } \\
\text { Dry Weight }\end{array}$ & $\begin{array}{l}\text { Harvest } \\
\text { index }\end{array}$ \\
\hline & $\mathrm{gm}$ & $\mathrm{Gm}$ & $\mathrm{gm}$ & $t_{h a}{ }^{-1}$ & $\mathrm{tha}^{-1}$ & $\mathrm{HI}$ \\
\hline Carslien & 630.8 & 92.5 & 83.7 & 18.02 & 2.64 & 0.15 \\
\hline Vezate & 578.3 & 73.0 & 81.7 & 16.52 & 2.09 & 0.13 \\
\hline Bostiyalnske & 382.7 & 72.3 & 73.0 & 10.93 & 2.07 & 0.19 \\
\hline Darae & 427.5 & 79.0 & 76.5 & 12.21 & 2.26 & 0.18 \\
\hline Tshass & 393.3 & 71.5 & 83.7 & 11.24 & 2.04 & 0.18 \\
\hline Kharfksky & 404.2 & 81.3 & 71.0 & 11.55 & 2.32 & 0.20 \\
\hline I SD $(005 \%) *$ & 1731 & 1579 & 1034 & - & - & \\
\hline CV \%** & 41.99 & 22.93 & 14.29 & - & - & \\
\hline
\end{tabular}

*Least significant difference

***Coefficient of variability; NS =not significant

Our results indicated that plant productivity is very important issue under stresses conditions and the selection of good cultivars that able to adapted to stress condition is a key issue in the agriculture productivity $[23,24,25]$. Also our results indicated that breeding and the use of salt-tolerant cultivars of triticale might be the most favorable approaches for harvesting higher grain yield of best quality under saline conditions.

\section{ACKNOWLEDGMENT}

This data is one of the research activities in the project "Adaptation to climate change in WANA marginal environments through sustainable crop and livestock diversification” supported by IFAD, AFESD, IDB and OFID.

\section{REFERENCES}

[1] Turk, A.M. and A.M. Tawaha, 2002. Seed germination and seedling growth of two barley cultivars under moisture stress. Research on Crop, 3(3): 467-472.

[2] Turk, A.M. and A.M. Tawaha, 2002. Response of six- row- barley to seeding rate and weed control methods under moisture stress. Agricultura Mediterranea, 132(3/4): 208-214.

[3] Turk, A.M. and A.M. Tawaha, 2002. Irrigated Winter Barley Response to Seeding Rates and Weed Control Methods under Mediterranean Environments. Bulgarian Journal of Agricultural Science, 8(2-3): 175-180.

[4] Turk, A.M. and A.M. Tawaha, 2002. Response of sorghum genotypes to weed management under Mediterranean conditions". Pakistan Journal of Agronomy, 1(1): 31-33

[5] Turk, M.A, A.M. Tawaha, H. Taifor, A. Al-Ghzawi, I.W. Musallam, G.A. Maghaireh, Y.I. Al-Omari, 2003. Two row barley response to plant density, date of seeding and rate and method of phosphorus application in the absence of moisture stress. Asian Journal of Plant Science, 2(2): 180-183.

[6] Turk, M.A., A.M. Tawaha, N. Samara and N. Latifa, 2003. The response of six row barley (Hordeum vulgare L.) to nitrogen fertilizer application and weed control methods in the absence of moisture stress. Pakistan Journal of Agronomy, 2(2): 101-108.

[7] Turk, M.A., K.M. Hameed, A.M. Aqeel and A.M. Tawaha, 2003. Nutritional status of durum wheat grown in soil supplemented with olive mills by products. Agrochimica, XLVII(5-6): 209-219.

[8] Turk, M.A., A.M. Tawaha, O. Nikus and M. Rifaee, 2003. Response of Six-Row Barley to Seeding Rate with or without Ethrel Spray in The Absence of Moisture Stress. International Journal of Agriculture and Biology, 4: 416-418.

[9] Turk, M.A., A.M. Tawaha, O. Nikus and M. Rifaee, 2003. Impact of Cultural Practices on Yield Variability of semiarid wall barley (Hordeum murineum). International Journal of Agriculture and Biology, 4: 432-434.

[10] Seguin, P., W. Zheng, W. Souleimanouv, D.L. Smith and A.M. Tawaha, 2003. Effects of cultivars and fertilization on soybean isoflavone content. Canadian Journal of Plant Science, 84: 254.

[11] Turk, M.A., A.M. Tawaha and M. Shatnawi, 2003. Lentil (Lens culinaris Medik) Response to plant density, sowing date, phosphorus fertilization and Ethephon application in the absence of moisture stress. Journal of Agronomy and Crop Science, 189(1): 1-6.

[12] Turk, M.A. and. A.M. Tawaha, 2003. Effects of seeding rate and date, and phosphorus application on growth and yield of narbon vetch (Vicia narbonensis). Agronomie, 23: 1-4.

[13] Tawaha, A.M., V.P. Singh, M.A. Turk and W. Zheng, 2003. A review on growth, yield components and yield of barley as influenced by genotypes, herbicides and fertilizer application. Research on Crop, 4(1): 1-9.

[14] Tawaha, A.M. and M.A. Turk, 2004. Field Pea Seeding Management for Semi-arid Mediterranean Conditions. Journal of Agronomy and Crop Science, 190: 86-92. 
[15] Turk, M.A., A.M. Tawaha and K.D. Lee, 2004. Seed Germination and Seedling Growth of Three Lentil Cultivars under Moisture Stress. Asian Journal of Plant Science, 3(3): 394-397.

[16] Nikus, O., M.A. Turk and A.M. Al-Tawaha, 2004. Yield response of sorghum (Sorghum bicolor L.) to manure supplemented with phosphate fertilizer under semi-arid Mediterranean conditions. International Journal of Agriculture and Biology, 6(5): 889-893.

[17] Nikus, O., M.A. Turk and A.M. Al-Tawaha, 2004. Effect of manure supplemented with phosphate fertilizer on the fodder yield and quality of two sorghum cultivars (Sorghum bicolor L.). Bioscience Research, 1(1): 1-7.

[18] Musallam, I.W., G. Al-Karaki, K. Ereifej and A.M. Tawaha, 2004. Yield and Yield Components of Faba Bean Genotypes Under Rainfed and Irrigation Conditions. Asian Journal of Plant Science, 3(4): 439-448.

[19] Tanji, K.K., 1990. Nature and extent of agricultural salinity. Agricultural salinity assessment and management, K.K. Tanji (Ed.). Amer. Soc. Civil Eng., ASCE. Manuals and Reports on Engineering Practice No.71. ASCE. New York, USA, pp: 1-17.

[20] Cramer, G.R. and D.C. Bowman, 1994. Cell elongation control under stress conditions. In: M. Pessarakli (Ed.), Handbook of plant and crop stress. Marcel Decker New York. NY, USA, pp: 303-320.

[21] Leidi, E.O., M. Silberbush and S.H. Lips, 1991. Wheat growth as affected by nitrogen type, pH and salinity. I. Biomass production and mineral composition. J. Plant Nutr., 14: 235-246.

[22] Shuqin, W., J. Yanping, K. Yaohu, J. Shufang, T. Junli, L. Wei and M. Jing, 2013. Growth and yield of oleic sunflower (Helianthus annuus L.) under drip irrigation in very strongly saline soils, Irrigation Science, 31(5): 943.

[23] Al-Tawaha, A.M., P. Seguin, D.L. Smith, R.B. Bonnell, 2007. Irrigation level affects isoflavone concentrations of early maturing soya bean cultivars. Journal of agronomy and crop science, 193(4): 238-246.

[24] Abebe, G., B. Hattar, A.R.M. Al-Tawaha, 2005. Nutrient availability as affected by manure application to cowpea (Vigna unguiculata L. Walp.) on calacarious soils. Journal of Agriculture and Social Sciences, 1(1): 1-6.

[25] Turk, M., A. Tawaha, N. Samara, 2003. Efects of seeding rate and date and phosphorus application on growth and yield of narbon vetch (Vicia narbonensis). Agronomie, 23(4): 355-358. 